\title{
Self-Translation in the Northern Renaissance: Jan van der Noot's French Verse
}

\author{
Adrian Armstrong \\ Queen Mary University of London \\ a.armstrong@qmul.ac.uk \\ https://orcid.org/OOOO-OOOI-6299-430I \\ Received: 22/04/202O; accepted 02/06/202O. \\ DOI: https://doi.org/I0.7203/MCLM.7.I7I77
}

\begin{abstract}
The Brabantian poet Jan van der Noot (I539-95?) wrote in both Dutch and French, and composed several works in both languages. Sometimes the two versions were published separately: the Dutch collection Het Theatre and its French counterpart, Le Theatre, were each printed in London in I568. More often, the versions appeared alongside each other in bilingual editions: Cort begryp der XII boeken Olympiados / Abregé des douze livres Olympiades (I579), Lofsang van Braband / Hymne de Braband (I580), and various short pieces reproduced in anthologies of Van der Noot's poetry (I580-95). The present study contends that Van der Noot's self-translations should be read as translations from Dutch to French, rather than from French to Dutch as scholars have commonly assumed. It examines Van der Noot's selftranslational strategies, focusing in particular on his handling of form and versification, and the role played by paratext and illustrations. In doing so, it offers an alternative perspective on a figure whose translational activity is generally considered to have operated in the opposite direction, introducing innovations into Dutch poetry by imitating the work of Ronsard and the Pléiade.
\end{abstract}

\section{KEYWORDS}

Jan van der Noot; self-translation; versification; paratext; bilingual printing; early modern literature; Dutch poetry;

French poetry

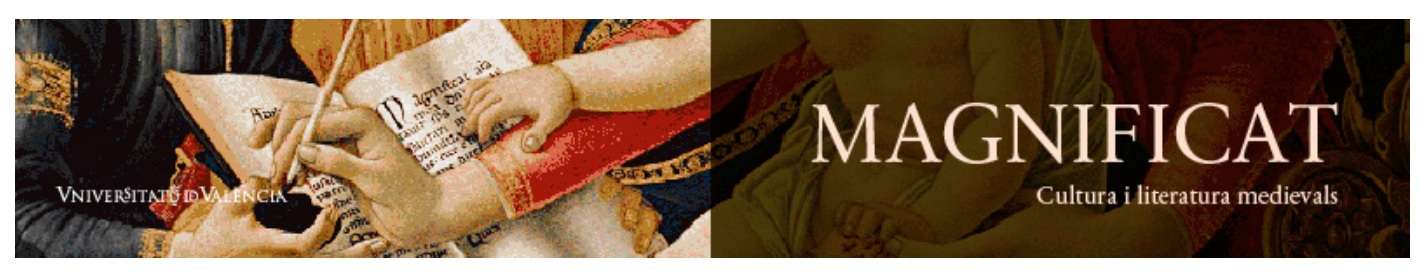

Magnificat Cultura i Literatura Medievals 7, 2O2O, 2II-233. http://ojs.uv.es/index.php/MCLM

ISSN $2386-8295$ 
RESUM

El poeta de Brabant Jan van der Noot (I539-95?) va escriure tant en holandès com en francès, i va compondre diverses obres en ambdós idiomes. De vegades les dues versions es van publicar separadament: el recull holandès Het Theatre i el seu contrapart francès, Le Theatre, van ser els dos impresos a Londres en I568. Més sovint, les versions apareixien l'una al costat de l'altra en edicions bilingües: Cort begryp der XII boeken Olympiados / Abregé des douze livres Olympiades ( 579), Lofsang van Braband / Hymne de Braband (580), i diverses peces curtes reproduïdes en antologies de la poesia de Van der Noot (I580-95). El present estudi argumenta que les autotraduccions de Van der Noot s'han de llegir com a translacions de l'holandès al francès, i no del francès a l'holandès com els estudiosos donaven per fet. S'hi examinen les estratègies d'autotraducció de Van der Noot, i en particular el seu maneig de la forma i de la versificació, així com el paper que juguen el paratext i les il·lustracions. D’aquesta manera s'ofereix una perspectiva alternativa d'una figura l'activitat traductora de la qual s'ha considerat que operava en sentit contrari, introduint innovacions en holandès en imitar l'obra de Ronsard i de la Pléiade.

PARAULES CLAU

Jan van der Noot; autotraducció; versificació; paratext; impressions bilingües; poesia de l'edat moderna; poesia holandesa; poesia francesa

Adrian Armstrong. 2020. 'Self-Translation in the Northern Renaissance: Jan van der Noot's French Verse', Magnificat Cultura i Literatura Medievals, 7: 2II-233, DOI: https://doi.org/IO.72O3/ MCLM.7.I7I77 (co) Br

\section{TABLE OF CONTENTS}

I Introduction - $2 \mathrm{I} 3$

2 Van der Noot's career and publications $-2 \mathrm{I} 3$

3 Dutch and French: questions of precedence $-2 \mathrm{I} 6$

4 Translational strategies: form and versification $-2 \mathrm{I} 8$

5 Translational strategies: paratext and illustration -225

6 Conclusion - 229

7 Works Cited - 23I 


\section{ə*⿻丷木}

\section{Introduction}

The Brabantian poet Jan van der Noot (I539-95?) wrote in both Dutch and French. ${ }^{\mathrm{I}}$ In itself, this practice was not unusual for early modern poets from the Low Countries (Van de Haar 2019: 69-72). What makes Van der Noot's output much more distinctive is that he composed a number of works in both languages. In some cases, the Dutch and French versions were published alongside each other, maximizing the poet's potential audience and advertising his compositional skill. Van der Noot is generally considered to have channelled elements of French literary culture into the Low Countries, introducing innovations into Dutch poetry by imitating the work of Ronsard and the Pléiade (Brachin 1959; Keizer-Richardson 2OI2: I2-I3). Partly for this reason, he is often thought to have composed the French versions of his bilingual pieces first, before translating them into Dutch. However, there are good reasons to re-evaluate this assumption, and take at face value the poet's indications - both explicit and implicit - that he originally composed these pieces in Dutch and subsequently translated them into French. In what follows I present the case for reading Van der Noot's self-translation as a Dutch-French rather than French-Dutch process. On that basis I examine his translational strategies in various compositions, focusing specifically on his handling of form and versification, and on the role played by paratext and illustrations. This analysis offers an alternative perspective on the intercultural position of a significant poet of the Northern Renaissance.

\section{Van der Noot's career and publications}

Re Warschoot ed. 1975: 2, 16-18; Bostoen 1997: 49-5; Meeus 2018). Born ifl an 242-45, Waterschoot ed. I975: 2, I6-I8; Bostoen I997: 49-51; Meeus 20I8). Born into an established patrician family, he was an alderman of Antwerp on two occasions while still in his twenties. He converted to Protestantism at some point in the mid-I56os, and was one of the leaders of an unsuccessful Calvinist revolt in Antwerp in March 56 6 . Accompanied by his manservant Dries, though not by his wife, he fled to London, where he remained until departing for Cologne in autumn I57. The Pacification of Ghent in November 5576 enabled him to return to the Low Countries, albeit not before he travelled to northern Italy, southern France, and Paris, where he met Ronsard and Dorat. He was back in Antwerp by I578, by which time he had reconverted to Catholicism; at any rate his published work from $157^{8}$ onwards is increasingly Catholic in orientation (Waterschoot I974: 80-83). His efforts to make a living as a professional author, notably by requesting financial

I. Van der Noot himself always refers to his West Germanic dialect as Brabantian, both when writing in that dialect and when writing in French: d'Brabandts sanck, 'the song of Brabant'; Brabantsche sprake, 'Brabantian language' (Waterschoot ed. I975: 2, 205, 368); brabançon, 'Brabantian' (Zaalberg ed. I956: I37); Langue brabançonne, 'Brabantian language' (Zaalberg ed. 1956: I37; Waterschoot ed. 1975: 2, 368). I use ‘Dutch' throughout this study, in accordance with standard practice in research on early modern literature in the West Germanic dialects used in the Low Countries (Van de Haar 2OI9: 2I-25). Orthography and punctuation in quotations from early editions (including those reproduced in facsimile by modern editors) are normalized in accordance with standard editorial practice. Translations are my own. 
support from the States of Brabant, met with little success (Waterschoot 1974: 76). Any prospect of official recognition disappeared after the Fall of Antwerp in $5_{585}$; Van der Noot largely withdrew from public life, and developed increasingly cosmopolitan perspectives on poetry. His latter years are very sparsely documented; he is not recorded as alive after April I595, but no clear indications of his death exist until almost six years later.

Specialists have found it difficult to reconstruct Van der Noot's publishing career: a number of editions pose significant bibliographical challenges, quite apart from the poet's tendency to reuse not only compositions but also printed sheets. ${ }^{2}$ As far as literary historians can tell, the first book-length edition to bear his name was Het Theatre, printed by John Day of London in ${ }_{5} 568$ (USTC 5068I8). Day published a French version, Le Theatre, shortly afterwards (USTC 56373 ). The immediate audiences of both versions primarily comprised communities of religious refugees in London. Van der Noot explains his aims in a dedicatory epistle to Roger Martin, Lord Mayor of London, which appears in the Dutch edition. He seeks to demonstrate that earthly concerns are worthless, and thereby to encourage the elect - namely Protestants in the Low Countries - to persevere in their faith and resist their Spanish oppressors' appeals to their avarice, pride, and sensual desire (Smit-Vermeer ed. I953: 37-38, 19O-92). Both the Dutch and the French editions present a sequence of epigrams and sonnets, each accompanied by a specially designed allegorical copperplate engraving, followed by prose commentaries. The commentaries take up the majority of space in each edition; some scholars have seen them as the real core of Van der Noot's project (SmitVermeer ed. 1953: 38-39; Brachin 1959: 6; Waterschoot 1997: 44 disagrees). They develop broadly Protestant arguments, supported by references to classical and patristic authors, historical works, and the Bible (Witstein I965). ${ }^{3}$ The poems themselves form three successive groups. Six epigrams by Clément Marot, based on the six stanzas of Petrarch's canzone 323, are followed by eleven of the fifteen sonnets of Joachim Du Bellay's Songe (the second half of his Antiquitez de Rome); the Dutch translations in Het Theatre seem to be Van der Noot's own. ${ }^{4}$ The pieces by Marot and Du Bellay underline the transience of earthly beauty and power respectively, and thereby prepare the ground for the final group of poems: four sonnets by Van der Noot, heavily based on the Book of Revelation, on the punishment of the impious and the salvation of true believers at the Last Judgement (SmitVermeer ed. 1953: 228-31; Van der Noot I568: D2v-D6r). Van der Noot's sonnets generate much more commentary than the preceding poems, though the commentary focuses on the Biblical text rather than the sonnets themselves (Waterschoot 1997: 44). The engravings are generally ascribed to Marcus Gheraerts I, who had illustrated the Warachtighe Fabulen der Dieren (USTC 40I3I9) published in Bruges in ${ }_{5567}$ (Smit-Vermeer ed. 1953: 45; Waterschoot 1997: 45; Friedland 1956 is more doubtful). A religious exile like Van der Noot, Gheraerts had arrived in England in March I568. An English version of the collection, generally known to scholars as A Theatre for Voluptuous Worldlings, appeared in ${ }_{5} 69$ (USTC 50698I). Published by Henry Bynneman, with woodcuts by an unknown artist copied (mostly in reverse) from the original engravings, this version was doubtless aimed at a wider public. The prose commentaries were translated by Theodore Roest; the verse was translated by the young Edmund Spenser, working largely though not exclusively from the French version (Melehy 2OIO: 96-II2; Hadfield 2OII). In I572 the Cologne printer Gottfried Hirtzhorn published a German version, Theatrum das ist Schawplatz, translated by Balthasar Froe and using the woodblocks from Bynneman’s English edition (Schlusemann 20II: 409).

2. Smit-Vermeer ed. 1953: 37 col. I n. 2 notes various works that are now lost.

3. Jan van Dorsten (1970: $77_{-78}$ ) notes that the commentaries are not specifically Calvinist in inspiration, as earlier scholars had often supposed.

4. The handling of verse suggests that Van der Noot used Petrarch as well as Marot in translating the latter's work. 
Het Bosken (The Grove), a poetic anthology datable to I57I, was another London publication (Smit-Vermeer ed. 1953: 13-34; Waterschoot 1992). It was printed by Bynneman for the most part, though the final two gatherings were printed by Day, apparently to speed up the production process. The Bosken's contents are thought to predate Het Theatre; they comprise occasional, amatory, and religious pieces in Dutch, French, and Latin, as well as exchanges of compliments in various languages with other authors. Evident influences on these youthful compositions include Petrarch, Ronsard, Baif, and Marot, some of whose Psalms are included in Dutch translation. Some material had already appeared in print; an exchange of complimentary verses with Guillaume de Poetou, for instance, figures in Poetou's Suite du Labeur en Liesse (USTC 37164), published in Antwerp in I566 (Smit-Vermeer ed. I953: 67-77, 94-96, 358-59; Bostoen 20I6). Surviving copies attest to different states of preliminary material, suggesting that they may have been addressed to individual recipients as prospective patrons; certainly the Bosken's prospective public seems more limited than that of Het Theatre. Hirtzhorn reissued the Bosken sheets in I572, with two new preliminary gatherings, under the title Verscheiden poetixe wercken (Various Poetic Works; USTC 4I5393). The new material comprises fifty poems in French and Dutch in praise of potential patrons based in Cologne, both Protestant emigrants from the Low Countries and leading local jurists (Porteman-Waterschoot ed. 1990). While a fascinating collection in own right, the Bosken contains no self-translations; I therefore exclude it from analysis.

Van der Noot's most substantial enterprise was an epic poem in twelve books recounting, in the form of a first-person narrative, the journey of the poet's soul through successive stages of temptation and purification towards heaven, where divine love is personified as Olympia. The complete work was never published, and may indeed never have been finished. A version in German, entitled Das Buch Extasis (The Book of Ecstasy) and illustrated with engravings by Dirck Coornhert, appeared in Cologne in I576 (USTC 626729). Heinrich von Aich printed the text proper, while Felix Röschlin printed the Apodixe (Demonstration), a long prefatory dialogue that explains the allegorical motifs in two of the illustrations, outlines the nature of poetry, and lauds Van der Noot's work (Zaalberg I954; Zaalberg ed. I956: I-I23). Three years later, Gillis van den Rade published an abridged version in a bilingual Dutch/French edition (USTC 56454 ), reflecting the polyglot nature of Antwerp's literary and publishing culture (Swiggers et al. 20I8; Blanco 20I8; Meeus 20I8). Van den Rade's edition bears the double title Cort begryp der XII boeken Olympiados (Brief Summary of the Twelve Books of Olympia) / Abregé des douze livres Olympiades. The German, Dutch, and French poems are all in decasyllabic verse, though Das Buch Extasis includes more material than the other versions. In particular, while the Cort begryp/Abregé concludes with a banquet celebrating the hero's betrothal with Olympia, Das Buch Extasis narrates the hero's subsequent journey towards God, punctuated by various encounters and speeches. Though the German poem was published before the Cort begryp/Abregé, Van der Noot appears to have based it on the French text, at least for the portions that coincide across the different versions (Zaalberg I954: 74-IOI, 239-46). Carlo Zaalberg (I965: 258-59) has persuasively suggested that the publication of the incomplete Cort begryp/Abregé was a self-promotional move, whereby Van der Noot announced his return to the literary stage of the Low Countries as soon as possible after his return to Antwerp.

The following year, Van der Noot had a second bilingual edition printed by Van den Rade, the Lofsang van Braband (Ode to Brabant) / Hymne de Braband (USTC 56455; Zaalberg ed. 1958). This eulogy of the poet's native county was composed in early I578, before his return to the Low Countries; the Dutch and French versions are both in alexandrine couplets, and their content is very similar. Over a third of the Lofsang/Hymne is taken up by a long peroration, entitled Repetitio in both languages, which ends with the poet expressing his wish to achieve artistic recognition in 
Brabant. Van der Noot supports his claim for such recognition in a dedicatory epistle addressed to the States of Brabant, in which he exalts poetry, particularly his own (Zaalberg ed. I958: xxiv-xxv, ${ }^{*} 3^{-*} 6$ ). However, his attempt to secure official status as Brabant's public poet was in vain, and the Lofsang/Hymne would be the last substantial individual work that he published.

Not that Van der Noot fell silent at that point. On the contrary: over the next fifteen years he produced a substantial volume of shorter poems in Dutch and French, mostly praising individual aristocrats and merchants in return for financial support. These were published in two successive editions aimed at Antwerp's large audience of cultivated multilingual readers, each simply entitled Poeticsche Werken (Poetic Works). The editions are difficult to describe in bibliographical terms: they each comprise a set of sheets (bifolia) published over a period of some years, first by Van den Rade (I500-85), then by Daniel Vervliet and Arnout Coninx (I588-95). ${ }^{5}$ Accompanied by preliminary bifolia that were occasionally updated, the sheets were combined into individually personalized copies, apparently depending on availability rather than on a customer's literary or ideological preferences (Waterschoot I97I; Waterschoot ed. 1975: I, 9-2I3; Vosters 1985: 207-13). Although the content of these editions is multilingual - enhanced in the second edition by extensive commentaries in French, Castilian, and Italian -, it includes very little self-translated verse by Van der Noot.

\section{${ }_{3}$ Dutch and French: questions of precedence}

$\mathrm{V}_{\mathrm{a}}$ an der Noot's only explicit claim about the direction of self-translation appears towards the end of the liminary material that introduces the Cort begryp/Abregé. A brief prose summary of the narrative, or Argument, is supplied in both languages (Zaalberg ed. I956: I36-39). In its closing address to the reader, the French Argument includes a passage absent from its Dutch equivalent, directed specifically at "lecteurs tant romains que François", in other words French-speaking readers both within and outside the kingdom of France. The passage explains the poet's decision to make his work available in the language of a foreign audience: "après l'avoir composé en son brabançon, l'a luy mesme aussi mis en vostre François, pour par ce moien d'une honneste privauté et gentille audace monstrer le bon cœur qu'il porte aux gentils esprits de France" (Zaalberg ed. I956: I37). This may of course simply be the self-promotional strategy of a poet seeking to reach an audience in France as well as in his home city and region; but it signals very clearly to potential readers that the Abregé should be considered a translation of the Cort begryp.

Readers must infer the direction of Van der Noot's other self-translations, either from the presentation of bilingual editions or from the order in which Dutch and French versions were published. The order of publication of Het Theatre and Le Theatre suggests that Van der Noot's Dutch sonnets may predate their French equivalents, though few members of the contemporary audience may have known which edition appeared first. For readers of the Lofsang/Hymne, by contrast, layout very clearly implies that the Lofsang precedes the Hymne. The Dutch title appears first on the bilingual title-page; the two poems are laid out in parallel, with Dutch on the left-hand side of an opening and French on the right-hand side; when one of the pages in an opening contains a woodcut image, the facing page bears text in both languages, with the Dutch version placed

5. Perhaps inevitably, the USTC numbers for the two editions are confused. The set of copies comprising the first edition corresponds to USTC 37200,56565 , 40I898, 4065I9, 4I 479I, and 4I4880. The set comprising the second edition corresponds to USTC 798II, 79816, 80797, 80798, 80799, 80880, 83007, 9I45I, 349442, 349443, 349930, 350699,350834 , and 440595 . 
above the French. ${ }^{6}$ Similarly, paratext presents the edition as an enterprise primarily conceived and developed in a Dutch-speaking environment. While the printer's details on the title-page are supplied only in French, the running titles are exclusively in Dutch. Neither the epistle to the States of Brabant, nor a laudatory poem addressed to Van der Noot by the Antwerp artist and rhetorician Pieter Balten (Zaalberg ed. 1958: 34), is accompanied by a French translation. All these elements cast a particular light on the epistle, in which Van der Noot claims that he composed his poem "in de twee talen die in Brabant natuerliick ghesproken worden" (in the two languages spoken by natives of Brabant; Zaalberg ed. 1958: *6). The order of the versions' composition is not specified, but must have seemed obvious to his audience.

In the Poeticsche Werken, the effects of layout are similar to those in the Lofsang/Hymne: in the rare instances of verse self-translation, Dutch is presented as the prior language. The first edition contains six short pieces in Dutch and French, including four sonnets, of which two had previously appeared in Dutch in Het Bosken (Smit-Vermeer ed. 1953: I22, 130). The corresponding versions have identical versification, and are presented in parallel across the openings of a single bifolium, with Dutch on the left-hand page and French on the right (Waterschoot ed. 1975: 2, 253-58; 3 , I3I-34). The sonnets are reprinted with minimal modifications in the second edition (Waterschoot ed. I975: 2, 4II-I $4 ; 3,284-85)$. Here the layout is sequential, with Dutch text on the recto followed by French text on the verso. A more substantial self-translation figures in the second edition alone, where a Dutch poem addressed to the Antwerp merchant Marcus van Wonsel is accompanied by a French piece to the Walloon soldier Ancelme de David (Waterschoot ed. 1975: 2, 367-70; 3, 24I-45). Besides their distinct addressees, these pieces are very different in formal terms, and their content is only approximately equivalent. However, they are presented in a way that invites readers to treat them as an instance of self-translation: the Dutch title and a versified introduction are followed by their French equivalents, then each poem is arranged in parallel columns. This intriguing pair of compositions repays closer attention, and I return to it below.

If so many features of Van der Noot's editions suggest that he translated his verse from Dutch to French, why have so many scholars assumed the contrary? Their attitude relies on arguments advanced by Carlo Zaalberg, primarily in relation to the Cort begryp/Abregé, which have not subsequently been contested (I954: 8I-84). ${ }^{7}$ Yet Zaalberg presented his findings not as conclusive, but rather as casting a measure of suspicion on the claim in the French Argument that the Cort begryp predated the Abregé. What is more, these findings depend heavily on assumptions of an aesthetic kind. Zaalberg notes, for example, the presence of formulaic phrases in the Dutch verse that seem to act as fillers (1954: 82-83). However, such phrases may be motivated simply by concerns of metre rather than translation. After all, Van der Noot was writing French-style isosyllabic verse, which posed a more difficult formal challenge than the stress-based metres that had been traditional in Dutch poetry (on which see more below). That challenge is apparent in the work of many early modern poets who worked exclusively in French, where there is no shortage of such fillers. ${ }^{8}$ Similarly open to challenge is Zaalberg's suggestion that some of the rhymes in the Cort begryp seem to have been adopted from a French-language source (1954: 83-84). Gallicisms were not at all uncommon in literary Dutch of this period - nor indeed in that of earlier generations (Sutch 2OI7) -, particularly in the work of authors whose habits had been formed in multilingual settings.

6. Parallel layouts of this kind, and the chronological relationships between versions that they construct, take a variety of forms in the sixteenth-century Low Countries (Armstrong, forthcoming).

7. Zaalberg is cited by, for example, Brachin (เ959: 6) and Meeus (2018: 677).

8. Zaalberg makes the same argument in relation to the Lofsang/Hymne (Zaalberg ed. I958: xxi). It must be treated with caution for the same reason. 
We cannot, then, consider Zaalberg's arguments as incontrovertible, let alone elevate them into a principle that underlies Van der Noot's working practices as a whole. Perhaps later scholars have accepted them uncritically because the poet's debt to Marot and the Pléiade is so obvious. That debt is apt to encourage the perception that Van der Noot's compositions must have originated in the language of his models. To accept that perception without scrutiny, however, is tantamount to the "cultural cringe", the fallacy that whatever a particular culture produces must be inferior to the cultural products of a former colonizer or a powerful neighbour (Phillips I950).

Hassan Melehy makes a more constructive suggestion when considering Van der Noot's four sonnets in Het Theatre and its French equivalent: "It is not known whether van der Noot composed the Dutch or the French versions of his four sonnets first; he was fully conversant in both languages, and it is likely that he revised the two sets simultaneously" (Melehy 20IO: 97 n. 5). This seems entirely reasonable, in respect of both these 1568 publications and his other self-translations, in the absence of concrete evidence to the contrary. It is almost inconceivable that Van der Noot did not complete his self-translations by revising the two versions against each other, to ensure an optimum fit in both semantic and formal terms. From this perspective, the question of which text came first simply becomes irrelevant - bearing out the contention, advanced by Jan Walsh Hokenson and Marcella Munson (2007: 3-4, 206-O7), that the process of self-translation does not easily lend itself to the vocabulary of source and target languages, texts, and cultures with which translation studies typically works. Nevertheless, in the case of Van der Noot, we must take account of the implied author constructed by the paratexts of his published material. Any process of literary reception generates an implied author, in the sense of a creative intelligence to which the readers of a text will ascribe decisions, regardless of what the historical author's views and strategies may have been (Richardson 2OII). In early modern literary publishing, however, material such as prefaces, dedications, and commentaries often plays a key role in delineating that intelligence, not only for individual works but also for an author's output as a whole (Armstrong 2OOO: 2IO-I4). ${ }^{9}$ Most of Van der Noot's paratexts at least imply that he initially composed his work in Dutch before translating it into French. We must therefore assume that this is how contemporary audiences approached his bilingual texts and evaluated his achievement, whatever their own linguistic competences may have been - and at this point it is worth remembering that his audience was likely to have been largely bilingual, if not necessarily equally competent in both languages (Swiggers et al. 2018). It makes sense, in short, to take the paratextual messages at face value, and to consider what strategies we might ascribe to the implied author that those messages generate.

\section{Translational strategies: form and versification}

$\mathrm{T}$ he technical aspects of verse form are an ideal starting-point for any analysis of Van der Noot's approach to self-translation, since they are so central to his poetic practice. His most significant intervention in the history of poetry in Dutch is the use of French-style syllabic versification in the vast majority of his work, as opposed to the stress-based versification that had previously been typical. ${ }^{\text {Io }}$ Other poets had previously used syllabic verse in Dutch, but Van der Noot was the first to practise it so extensively and rigorously, paying unprecedentedly close attention to the role of

9. Brian Richardson (2OII: 6, 8) considers the notion of the "career implied author".

IO. In the early sixteenth century, lines of Dutch verse typically contained between ten and fourteen syllables, with three or four stresses (Kossmann I922: 30 ). 


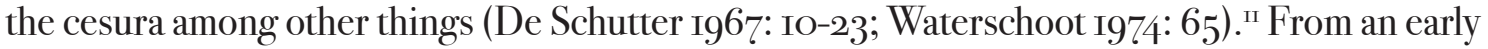
stage he paid close attention to detail, devising a system of accents to clarify the syllabic counts in Het Bosken (Waterschoot 1988; Porteman-Waterschoot ed. I990: 42-44). As his career developed, the formal rigour of his verse tended to increase; this sometimes entailed the revision of earlier compositions before they were republished (De Schutter i967: 84).

In a poem addressed to the Antwerp schoolmaster Étienne de Walcourt, included in the second edition of the Poeticsche Werken, Van der Noot claims to have innovated by using three types of verse in Dutch:

Soo heb'ick (soomen siet) vry onbedwonghen, In mynder moeders tael', zyn eer ghesonghen, Als die aerdighlyk ierst in d'Brabandts sanck Heerlyke veerschen schoon, hoogh van geclank; Oock ghemeyn veerschen suet; en diesghelycke, Lirische veerschen licht, in woorden rycke (Waterschoot ed. 1975: 2, 205). ${ }^{12}$

('So I have sung His [sc. God's] praises, wholly without compulsion as is evident, in my mother tongue, skilfully using - before any others who sing the song of Brabant - epic verses, beautiful and lofty-sounding; also sweet-sounding common verses; similarly, delicate lyric verses; all rich in words'.)

The terms used here had previously figured in a long prose Apologie that forms part of the first Poeticsche Werken edition (Waterschoot ed. 1975: 2, 160-67). The Apologie, which praises Van der Noot's work and defends it against criticism, is attributed to the poet's admirer Hendrik Ackermans but may well have been authored - or at least conceived - by Van der Noot himself (Waterschoot ed. I975: 2, 89-98; 3, I5-28). It similarly refers to three types of verse:

[...] te weten heerlijcke, ghemeyne, ende lyricksche veerschen. D'eerste bestaende de manlijcke in I2. de vrouwelijcke in I3. sillaben, hebbende beyde sekeren snede, pause oft steunen op de seste sillabe. De tweede manire van veerschen, hebben de manlijcke Io. en de vrouwelijcke Ir. sillaben, ende hebben beyde de pause, snede, oft steunen op de vierde sillabe. [...] De derde manière syn van $2,3,4,5,6,7,8$ oft 9 sillaben na dat de wyse, sangh', oft harmonie is, der hymnen, oden oft der lyrikens diemen maken wilt (Waterschoot ed. 1975: 2, I60).

('... namely epic, common, and lyric verses. The first comprise twelve syllables for masculine lines and thirteen for feminine ones; both have a certain break, pause, or emphasis on the sixth syllable. In the second type of verse, masculine lines have ten syllables and feminine ones eleven, and both have the pause, break, or emphasis on the fourth syllable. [...] The third kind are of two, three, four, five, six, seven, eight, or nine syllables, according to whether the type, song, or harmony [i.e. metre] to be

II. Of previous examples of syllabic verse in Dutch, the best known is Lucas d'Heere's 565 anthology Den Hof en Boomgaerd der Poësien (USTC 403227), which includes various translations and adaptations of poems by Clément Marot. The first piece in French-style decasyllables known to have been published in Dutch is by Carel Utenhove; it figures in a multilingual anthology that Utenhove edited in ${ }_{5} 560$ while based in Paris (USTC I52896). Other early practitioners of forms deriving from French models include, among others: Philips of Marnix, lord of Sainte-Aldegonde, a bilingual Calvinist diplomat whose work includes two sonnets in Dutch composed in the I57Os, and who used a syllabotonic version of the alexandrine; and Peeter Heyns, a schoolmaster and rhetorician who adopted French-style isosyllabic verse between I568 and I577. See Forster 1967; De Schutter i967: Io; Waterschoot ed. i969; Waterschoot I995: I44-47; Van de Haar 2019: 23I-32, 292-93.

I2. On Walcourt and this poem, see also Waterschoot ed. I975: 3, II, 72. 
composed in is that of hymns, odes, or lyric pieces'.)

Ackermans (or Van der Noot) has drawn heavily on Ronsard's Abbregé de l'art poëtique François ( $5_{5}^{65}$ ), which makes a similar distinction between alexandrines, decasyllables, and shorter lines (Waterschoot ed. 1975: 3, I6). Ronsard had considered alexandrines as equivalent to "vers heroïques" in Latin and Greek; described decasyllables as "vers communs"; and claimed that shorter lines contain a variable number of syllables, specifically between three and eight (Laumonier ed. I949: 23, 26-27). The Apologie also follows Ronsard (Laumonier ed. I949: 24, 26) in referring to alexandrines and decasyllables with feminine endings, i.e. unstressed syllables after the rhyme, as containing thirteen and eleven syllables respectively. Its vocabulary somewhat blurs the question of whether the cesura in Van der Noot's verse should be considered as a pause or an emphasis. In practice, it serves primarily as an emphasis, albeit not necessarily a strong one, after which - in line with French practice - a final unstressed - $e$ is invariably assimilated to the following syllable and does not contribute to the overall syllable count (De Schutter I967: 54-58). ${ }^{13}$ All three types of verse - the 'epic' alexandrine, the 'common' decasyllable, and 'lyric' shorter lines - figure throughout Van der Noot's output, though in general terms alexandrines come to supplant decasyllables as the predominant metre from the Lofsang/Hymne onwards. Van der Noot largely follows Ronsard's precepts in using alexandrines for heroic subjects and decasyllables for amatory ones (De Schutter 1967: 24-28).

Various specialists (e.g. Van der Elst I922, Kazartsev 2OIO) have discussed the extent to which Van der Noot's Dutch verse can be considered as iambic, and hence as presaging the syllabotonic verse of later generations. By far the most thorough and illuminating study is that of Frans De Schutter (I967), who establishes convincingly that the verse is not iambic, but rather involves fixed stresses at the rhyme and, for alexandrines and decasyllables, the cesura. Elsewhere in a line, a flexible number of stressed syllables is distributed primarily according to ordinary word-and phrase-accent, though departures from ordinary accentuation can occur to maintain the principle of isochrony, whereby intervals between stressed syllables are broadly equal in duration (De Schutter I967: 95, 99). Leaving aside some elements that do not contribute strongly to his argument notably assumptions about isochrony that derive from principles of musical time -, De Schutter's findings come tantalizingly close to those of Roger Pensom, who developed a powerful model for identifying accent-distribution in French syllabic verse. Pensom's final refinement of this model outlines his principles as follows:

... low-frequency monosyllables and paroxytonic disyllables are accented and we mark oxytonic word-accent and countertonic word-accent on all polysyllables of low frequency of occurrence. Frequently occurring words of any length are consequently atonic. Any juxtaposed accents are subject to a deletion/displacement rule with respect to the informational priority of the accents concerned. Note must also be taken of syntactic boundaries within the verse-line which imply an accented position. Such boundaries can result in the accenting of a frequently occurring lexical item (Pensom 2OI8: 3O-3I). ${ }^{\mathrm{I}}$

In view of Van der Noot's literary influences, the coincidence between the rhythmic principles underpinning his Dutch verse and those inherent to French verse is hardly surprising. Hence

I3. De Schutter notes with interest that the very poem in which Van der Noot describes his metres, the piece to Étienne de Walcourt cited above, systematically departs from normal practice by placing a cesura at the sixth syllable of each decasyllabic line (I967: 57-58).

I4. An earlier formulation of these principles appears in Pensom I993: 36 . 
a potentially fruitful approach to his self-translational strategies lies in comparing accentual patterning, and the aesthetic effects that it generates, in equivalent passages of Dutch and French.

To this end I examine two samples of verse: an early example, the first of Van der Noot's four sonnets in Het Theatre and Le Theatre; and a later passage of similar length from the Lofsang/ Hymne. For the French versions, I identify accent-distribution on basis of Pensom's principles; in the notation that accompanies each line quoted below, $\mathrm{I}$ and o indicate stressed and unstressed syllables respectively. For the Lofsang extract, I follow the accent-distribution that De Schutter indicates for these lines (1967: I76-77). However, De Schutter's notation is appreciably different from Pensom's: it designates different kinds of stresses via a system of acute and grave accents and underlining. To enable clear comparisons with the Hymne extract, I therefore replace these signs by a more basic binary notation, where I designates both tonic and countertonic syllables, including those in positions where we might normally expect them to be unstressed. I apply the same simplified version of De Schutter's schema to the sonnet from Het Theatre.

This generates the following pattern of accent-distribution for the sonnet in Het Theatre. As in other examples below, (o) represents a final unstressed syllable - in other words a feminine ending and \# indicates that the cesura falls on the preceding syllable:

Wt der zee quam een beest' wel ghelijck den luyparde, Met pooten als den beyr, den mont den leeu gelijcke, Seven hoofden had sy, tien hoorné, en croonen rijcke: Namen des lasters oock aen heur hooft openbaerde. Den draeck gaf heur syn macht, synen stoel en sijn crachte.

Heur een hooft was gewont, maer is weerom genesen. D'eertryck verwondert hem, en heeft den draec gepresen.

Wie is seyden sij oock des diers gelyck in machte?

Noch een beeste sach ick op comen wt de eerde,

Twee hoornen hadse alst lam en sprack gelijck den drake

Doendé alle wonder werc voer hem en macht der beest

Die sij aenbidden doet en verleydt met geveerde

Des viers, het werelts volck en doet een beelde maken

Der beest' en gheeft hem om te spreken den gheest.

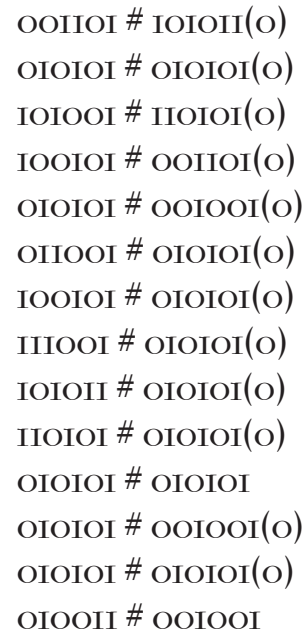

('Out of the sea came a beast, very like a leopard, with paws like a bear's and a mouth like a lion's. It had seven heads, and ten horns and rich crowns; and it bore names of blasphemy on its heads. The dragon gave the beast its power, its throne, and its force. One of its heads was wounded, but healed again. The world admired the beast and praised the dragon. "Who", they said, "is equal to the beast in strength?" I saw another beast rising up from the earth; it had two horns like the Lamb [of God], and spoke like a dragon, performing all kinds of wonders for the world to see, and wielding the power of the [first] beast, which makes the people of the world worship it with fiery wonders, and makes them create an image of the beast and give the image life so it can speak'. $)^{15}$

Significant effects result from clusters of accented syllables, which occasionally disrupt the iambic (огогог) and anapaestic (оогоо) rhythms more characteristic of ordinary speech. This is particularly apparent in the first line, where three pairs of adjacent stressed syllables set an initial tone of unsettling disruption. The stresses are determined positionally as well as linguistically, producing some unusual juxtapositions that are difficult to recite: around the cesura (beest'and 
the emphatic wel), and on successive syllables of luyparde (normal linguistic stress on the first syllable, stress required by the rhyme on the second). Throughout the rest of the sonnet, the second hemistichs almost exclusively follow iambic or anapaestic patterns. These contrast with clustered stresses in vv. 3 and 8; the former emphasizes the beast's monstrous nature, particularly its mathematically incongruous combination of heads and horns, while the latter signals the impiety of those who worship false gods.

The French version produces broadly similar rhythmic effects, through contrasts between clusters of stressed syllables and general iambic or anapaestic patterns:

Je vy sortir de mer une beste execrable,

Qui sept testes avoit, dix couronnes portant,

Et dix cornes, ayans ce vil nom blasphemant,

Et au fier leopart n'estoit pas dissemblable.

Elle eust les pieds d'un ours, la geule tout semblable

A celle d'un lion, et le dragon puissant

Luy donna son pouvoir ; et je vy tout sanglant

Une teste blessée, à la veoir merveillable.

« Ce dragon adoré », l'on crioyt haut et cler,

«Qui est semblable à elle et la pœult resister? »

Et lors sortoit de mer une beste sauvage,

Parlant comme un dragon, et faisant son pouvoir

Par grands signes de feu, pour un chascun mouvoir

D'adorer ceste beste en luy dressant l'image.

(Van der Noot I568: D2v)

\author{
OIOIOI \# OOIOOI(o) \\ OIIOOI \# IOIOOI(o) \\ OIIOOI \# OIIIOI \\ oOIOOI \# OIOIOI(o) \\ оIOIOI \# OIOIOI(o) \\ OIOOOI \# OOOIOI \\ OOIOOI \# OOIIOI \\ ooroor \# OoIOoI $(\mathrm{o})$ \\ OOIOOI \# OIOIOI \\ IOOIOI \# OOIOOI \\ OIOIOI \# OOIOOI(o) \\ OIOOOI \# OOIOOI \\ OIIOOI \# OOOIOI \\ oOIOOI \# OOOIOI(o)
}

Most notable in this instance are vv. 2-3, marked by two clusters in each line, including one around the cesura (v. 2, corresponding with a similar cluster in v. 3 of the Dutch) and the only group of three successive stresses in the poem (v. 3).

Though rhythm functions similarly in the two pieces, the handling of the sonnet form is appreciably different. The piece from Le Theatre uses just two rhymes in the quatrains, and observes an alternation of masculine and feminine rhymes, in line with French practice. ${ }^{6}$ The Dutch text, by contrast, introduces two new rhymes for the second quatrain, and only the final rhyme in the tercets is masculine. The same applies to Van der Noot's other self-translations in these anthologies: in each case the French sonnet is more rigorous by contemporary standards. ${ }^{17}$ Hence if we read Van der Noot's sonnets in Le Theatre as translations of those in Het Theatre, then the process of selftranslation involves perfecting the use of form - even if the results are unremarkable for audiences familiar with recent generations of French poets..$^{18}$

I6. In the rhyme scheme $a b b a$ abba $c c d$ eed, the $b$ - and $c$-rhymes are both masculine; this permits alternation to be maintained, since the quatrains end with one kind of rhyme and the tercets then begin with another. On this principle, see Laumonier ed. I925: $5^{8}$ n. 2.

I7. The second Dutch sonnet rhymes abba cddc eff egg; all rhymes are feminine. Its French version follows the same rhyme scheme, and the same pattern of masculine/feminine alternation, as the first French sonnet. The third Dutch sonnet has the same rhyme scheme as the first, abba cddc efg efg; all rhymes are feminine. Its French version follows the same scheme as its predecessors, the sole difference being that the masculine/feminine alternation begins in this case with a masculine rhyme. The final Dutch sonnet rhymes $a b b a$ cddc eef $g f g$; only the $a$ - and $g$-rhymes are masculine. Its French version maintains masculine/feminine alternation, but unexpectedly deviates from the standard rhyme scheme of the quatrains: abba acca ddeffe.

I8. The four self-translated sonnets published in the Poeticsche Werken reinforce the impression that French versions of earlier Dutch compositions are more formally rigorous. The two earlier Dutch pieces, originally published in $\mathrm{Het}$ 
I return to these sonnets below, but the next priority is to examine what Van der Noot is doing with rhythm in the Lofsang/Hymne a decade later. To begin with the Lofsang:

Maer, om lichamelijck van dees saken te spreken,

Soo moght ick my veel bat beclaghen, vol ghebreken,

Ghemerckt ick ben gheweest ghebannen, om mijn deughdt,

Wt u schoon edel landt; en daer toe, med cleyn vreughdt

Beroofdt van staet en goedt, en Kosmica misdadigh,

Die mijn welvaerdt en deughdt seer benijdt onghenadigh,

Soo dat ick was benoodt te dolen, stijf elf jaer,

Over al, en te sien veel landen, hier en daer;

Te bemerken d'bedrijf, het doen, t'voordstel en d'nyghen

Van menigherley volck, midts sien, hooren, en swyghen;

Waer deur ick ben ontgaen allerley wederspoet,

Deur den lust tot het goedt, dat eewigh duren moet.

Wel aen, ick sie nu wel dat Godt in sulker veughen

My heeft om beters wil bepruefdt, na syn genughen,

Soo hy sijn kinderkens en vrinden ondertast,

Ghelijck als t'goudt in t'vier versocht word en verrast,

Om die na grooten storm, na heurlider verlanghen,

In sijn rijck eeuwichlijck d'leven te doen ontfanghen.

(Zaalberg ed. 1958: v. 327-44)

\author{
OIOIOI \# OOIOOI(o) \\ IIOIOI \# OIOIOI(O) \\ OIOIOI \# OIOIOI \\ OIIIOI \# OIOIII \\ OIOIOI \# OIOIOI(O) \\ OOIOOI \# IOIOOI(O) \\ OIOIOI \# OIOIII \\ IOIOOI \# IIOIOI \\ OOIOOI \# OIIOOI(o) \\ OIOIOI \# OIIOOI(O) \\ OIOIOI \# IOOIOI \\ OOIOOI \# OIOIOI \\ OIOIOI \# OIOIOI(O) \\ OIOIOI \# OIOIOI(O) \\ OIOIOI \# OIOIOI \\ OIOIOI \# OIOIOI \\ OIIIOI \# OOIOOI(o) \\ OOIIOI \# IOOIOI(O)
}

('Rather, to speak of these matters in physical terms: I might well consider myself miserable and burdened with misfortunes, since I was exiled from you, my fair and noble land, because of my virtue. Moreover, to my distress I was robbed of my status and goods. I therefore left sinful Kosmica, who bitterly hates my comfort and virtue, and was obliged to wander far and wide for more than eleven years; to see many lands, near and far; and to consider the business, behaviour, practices, and inclinations of many kinds of people, by seeing, hearing, and keeping quiet. I avoided all sorts of misfortune through doing so, and through my desire for the good that must endure eternally. Now I can clearly see that God has tested me in this way for my own good, as He puts to the test His children and those who love Him - in the same way that gold is assayed and oppressed in the fire - so as to have them receive in His kingdom, after a great storm, the eternal life that they desire'.)

In the opening lines, the important rhythmic effects derive from clusters of accented syllables. The apostrophized Brabant ( $u$ schoon edel landt) and the misery of exile (med cleyn vreughdt) are foregrounded and thereby contrasted in v. 33o. Two lines below, a further cluster around the cesura (deughdt \# seer) establishes a further contrast: between the real satisfactions of Brabant as previously emphasised, and the harmful effects of Kosmica, a figure who generally personifies impious worldliness but who in this instance may stand for the poet's wife (Zaalberg ed. I958: $5^{\circ}$ ). The laborious cluster of three stresses that ends v. 333, stïf elf jaer, is mimetic of the duration of exile; in the following line, the clustered accents around the cesura (sien \# veel landen) complement this motif by emphasizing exile's spatial dimension. In the next couplet, by contrast, the disruptions

Bosken, each rhyme abba abba cdd cee; alternation between masculine and feminine rhymes is not consistent. The rhyme scheme of the French versions is almost identical, the only difference being that the tercets of the second piece rhyme $c c d$ eed; both pieces maintain masculine/feminine alternation (Waterschoot ed. 1975: 2, 257-58, 4I3-I4). The later Dutch sonnets, however, are no less rigorous than their French versions. The former both rhyme abba abba cdd cee, the latter abba abba ccd eed; all four pieces maintain masculine/feminine alternation (Waterschoot ed. I975: 2, $255^{-5} 6$, $\left.4 \mathrm{II}-\mathrm{I} 2\right)$. 
stronger expressive charge. Also quite different from the Dutch poem are the effects of accentual patterning in the closing lines. The identical patterning of vv. 343-44 reinforces the text's message of transcendent closure, whereas the corresponding lines in the Lofsang convey a sense of the disruption preceding that closure. In these extracts, then, rhythm often does different things in the two languages, producing similar overall effects but also admitting of localized phenomena that are peculiar to each version.

\section{Translational strategies: paratext and illustration}

T he previous section might suggest that the implied author's handling of Dutch-French translation was less assertive - at least in its exploitation of rhythm as an expressive device - in Het Theatre and Le Theatre than in the Lofsang/Hymne. But the account of the earlier collection has been only partial; Van der Noot's verse self-translation cannot be separated from the engraving and commentary with which the verse interacts in both editions, and indeed from other paratexts.

Both the Dutch and the French sonnet are positioned on the left-hand side of an opening, facing an engraving that represents many but not all of the motifs that figure in each poem. ${ }^{19}$ Emerging from the sea is a beast with seven heads, each of which has one or (in three cases) two horns, in other words ten horns in all, with a crown around each. As the poems indicate, the beast's paws resemble those of a bear, whereas one of its heads - if not the others - closely resembles that of a lion. The beast's resemblance to a leopard, noted in both sonnets, is explained more fully in the commentaries in each language: the leopard's spots are interpreted as signifying inconstancy and untrustworthiness (Smit-Vermeer ed. 1953: 254, 255-56; Van der Noot I568: F5v, F6v). Yet in the engraving, the beast appears to be striped (Bostoen 1997: 55). A gap is apparent between image and poem, or at least between image and commentary. Further, while each poem refers to one or more blasphemous names (singular in French, plural in Dutch), no corresponding detail figures in the engraving. The commentaries, however, suggest that the motif may have been transposed. They identify the blasphemous names as ecclesiastical titles, an interpretation that careful readers could connect with the bishop's mitre worn by a figure who worships the beast in the engraving (Smit-

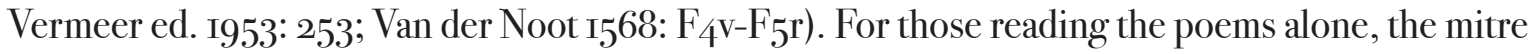
would suggest Van der Noot's disapproval of the proliferation of church offices; the commentary enables readers of either language to make the connection between those offices and blasphemous name(s). ${ }^{20}$ Both sonnets mention that one of the beast's heads is wounded; only the Dutch poem specifies that it promptly heals, though readers of Le Theatre can find that detail in the commentary (Van der Noot I568: F8r-GIr). In the engraving, one of the beast's heads is heavily shaded and hangs down lower than the others; readers might surmise this to represent the wounded head (Bostoen I997: 56).

The dragon, mentioned in both poems, is represented in the centre of the engraving. It has seven heads like the beast, a detail that figures in neither sonnet but in both commentaries, which interpret the dragon as Satan (Smit-Vermeer ed. I953: 252, 256; Van der Noot I568: F4v, F6v). Also mentioned in both poems are the people who worship the dragon and beast; these are depicted in

I9. The following analysis is indebted to, and builds on, Bostoen I997. The engraving can be viewed here: $<$ https:// go.uv.es/jbQnu7I > (Smit-Vermeer ed. I953: 228).

2O. The mitre is specifically mentioned in the commentaries, which describe it as figuring not the Old and New Testaments, in accordance with traditional symbolism, but rather duplicity and self-interest: Smit-Vermeer ed. I953: 269-7o; Van der Noot I568: G6v-G7r. 
the foreground of the engraving, and include the figure wearing the bishop's mitre. The tercets of Het Theatre introduce a second beast, with horns like those of a lamb, rising from the earth; in Le Theatre it rises from the sea, and its horns are not mentioned. The commentaries in both languages interpret this second beast as signifying false prophets; they refer to its horns and its emergence from the land (Smit-Vermeer ed. 1953: 267; Van der Noot I568: G5r). Yet neither commentary mentions fire, a prominent motif in both the poems and the engraving, where flames fill the sky behind the second beast (Bostoen I997: $5^{8-59}$ ). Further motifs in the image have no clear referent in either poem: two angels in the sky to the left and centre of the image, and God the Father apparently receiving a soul into heaven. These possibly correspond to elements mentioned in the commentaries: the nature of true believers, and the ultimate salvation of the elect (Smit-Vermeer ed. I953: 263, 265; Van der Noot I568: G3r, G4v).

What does all this imply for our understanding of Van der Noot's self-translation? The presence of the image and commentary seems to permit a certain semantic elasticity in the treatment of the poem. Some elements of the French sonnet are less developed, notably on the second beast and its actions. Others seem linguistically incoherent: "ce vil nom blasphemant" (v. 3) reads much more strangely than "noms de blaspheme" in the commentary (Van der Noot I568: G4v), while the masculine "dragon" is the antecedent of two feminine pronouns (vv. 9-IO). Rather than conveying closely equivalent content - or even content that always makes sense -, the implied author's priorities are evidently to maintain or enhance formal rigour, and to acknowledge as many elements in the engraving as possible (in the knowledge that elements not mentioned in the poem will be "swept up" by the commentary).

Other paratexts in Het Theatre and Le Theatre steer readers of each version in a broadly similar direction (Waterschoot 1997: 44-45). The text on the title-pages is very similar, and common to both editions is a Latin poem by Melchior van Baerle that encourages readers to repent (Smit-Vermeer ed. I953: I83-86; Van der Noot I568: Arr-A2v). Preceding Van Baerle's poem in Het Theatre are translated quotations from St Paul and St Jerome, setting a pious tone at the outset; following it are Dutch prose and verse texts by Gerardus Goossenius and Lucas d'Heere, complimenting Van der Noot on his eloquence but also acknowledging his religious message (Smit-Vermeer ed. I953: I85, I87-90). The liminary pieces end with the epistle to Roger Martin described above. In Le Theatre, Van Baerle's poem and the translated quotations bookend the other liminary pieces. Sonnets by the Protestant administrator Pierre d'Ennetières and by D'Heere, emphasizing the confessional thrust of Van der Noot's work, are followed by a dedicatory prose epistle by the poet to Elizabeth I, dominated by praise of the queen rather than religious polemic (Van der Noot I568: A3r-A8v). ${ }^{2 .}$ The French liminary materials, then, are less consistently oriented towards doctrinal matters than those in Dutch, but their sequential arrangement ensures that such matters remain prominent. The effect in both cases is to attune readers to the wider significance of what follows, encouraging them to interpret the poems from a religious perspective and to consult the commentaries to that end.

The paratext, illustrations, and presentation of the other editions containing Van der Noot's self-translations are no less significant. In the Cort begryp/Abregé, as previously noted, the French Argument - but not its Dutch equivalent - claims that the Cort begryp preceded its French counterpart. Yet in other respects, the edition establishes a delicate balance between the two languages, blurring impressions of chronological or thematic priority. On the title-page, the Dutch title comes first; but the the printer's details on that page, and the running titles throughout, are in French alone. The French Argument appears first, in contrast with the relative order claimed for the poems themselves. Moreover, while the French Argument clearly borrows elements from the Abregé,

2I. On D’Ennetières, see Waterschoot ed. I975: 3, I23.

Magnificat CLM 7, 2O2O, 2II-233. ISSN 2386-8295 
the Dutch Argument evinces no such debt to the Cort begryp; rather, it seems to be based on its French counterpart (Zaalberg ed. 1956: 263). As for the poems themselves, the Cort begryp figures on the left-hand side of each opening, or above the Abregé when one of the pages in an opening contains an engraving. In this respect, the layout reinforces the ostensible priority of the Cort begryp. The occasional engravings, however, somewhat redress the balance between the languages. The captions in each illustration are in Latin, ensuring that neither vernacular is privileged above the other. More importantly, the images demonstrably derive from the Arguments, not the poems themselves; in other words, they are based on a paratextual element that presents French as prior to Dutch (Wille 1952: 225 n. 8).

In the Lofsang/Hymne, we have already seen how paratext and layout construct a much more consistently chronological relationship between Dutch and French than in the Cort begryp/Abregé. The edition's four woodcut illustrations contribute to this process only through the bilingual verse caption to the first image, a portrait of Van der Noot based on an engraving used in the Cort begryp/Abregé (Zaalberg ed. I958: xxv-xxvi, ${ }^{*}$ ). . Here, as in the main text, Dutch verse precedes French. Textual elements in the other three images are all in Latin (Zaalberg ed. I958: xxvi-xxxi, 9, 25, 36); as in the Cort begryp/Abregé, they seem to stand apart from the processes of vernacular self-translation. The final woodcut raises further questions relating to language. It depicts an obelisk bearing inscriptions that are described as hieroglyphics, but that in fact function as rebuses; these largely derive from the French version of the Hypnerotomachia Poliphili attributed to Francesco Colonna, and convey a broadly didactic message that is outlined in Dutch and French on the preceding page. ${ }^{22}$ A similar engraving had appeared at the end of Das Buch Extasis; its constituent elements are interpreted at length in the Apodixe, and summarized in both Latin and German (Zaalberg ed. 1956: $3^{\mathrm{I}-33}$, I22). The Dutch and French interpretations in the Lofsang/ Hymne clearly derive from the summaries in the Apodixe, and do not clearly identify or explain the meanings of the individual hieroglyphs. Readers of the later work, then, may well find it difficult to make connections between a given hieroglyph and a particular phrase in the interpretations. Why, for instance, might the image of a snail represent the principle "vueghende u na den tijdt" (adapting to the season) or "t'accommodant selon le temps" (Zaalberg ed. I958: 35)? To explain the link, readers may have recourse to their pre-existing knowledge of texts, or indeed of the natural world; they may generate provisional readings and then discard them. ${ }^{23}$ Whatever their conclusions may be, the process of reading the hieroglyphs against their vernacular interpretations is likely to be laborious and challenging. More generally, any hieroglyph or rebus - irrespective of what it means suggest that meanings can be produced in ways that do not depend on any given language. ${ }^{24}$ Hence the closing image of the Lofsang/Hymne points towards the possibility, however spurious it may be in practice, of a transcendent order of meaning that reveals the contingency of all language systems. Contingency, however, is the condition with which human poets and human readers are obliged to deal. Indeed, it is a condition that Van der Noot embraces. The parallel presentation of the Dutch and French poems emphatically signals that both those languages are contingent, in a broadly

22. The artist has been tentatively identified as Johannes Ladenspelder of Essen. See Zaalberg ed. 1958: xxx-Xxxi.

23. The Apodixe elucidates the significance of the snail: "Wenn es schön wetter ist, steckt sie ire hörner auss; wenn as aber sturm und ungewitter ist, so zeugt sie sich in das heusslin, darinnen si sich erhelt, biss so lang die zeit besser ist” ("When the weather is fine, it sticks its horns out; however, when it is stormy, it withdraws into the little house in which it sustains itself, until a better moment comes along': Zaalberg ed. 1956: 29). On the ways in which rebuses mobilize and problematize their readers' existing knowledge, see Armstrong 2007.

24. In the case of this image, meanings are occasionally produced through wordplay, which depends on ancient languages rather than modern vernaculars. Guy de Tervarent's reading of the hieroglyphs (1997: 380-8I) notes these instances, though his interpretations sometimes diverge from Zaalberg's more reliable account (I954: 227-3I). 
Aristotelian sense: they could be otherwise than they are. ${ }^{25}$ For the poet of the Lofsang/Hymne, linguistic contingency plays a role similar to that of exile: it poses a set of challenges that he must work through on the way to glory.

To understand the effects of paratext and presentation on self-translation in the Poeticsche Werken, the most useful approach is to return to the poems addressed to Marcus van Wonsel and Ancelme de David. The forms of the two pieces are quite distinct, as previously noted; yet they fall into a single category that carries particular associations. Both compositions are heterometric: the stanzas in Dutch rhyme $a^{8} b^{8} a^{8} b^{8} c^{8} d^{4} c^{8} d^{8}$, with only the a-rhyme in each stanza being feminine; those in French rhyme $a^{6} a^{6} b^{6} b^{4} c^{6} c^{6} d^{6} d^{4}$, with consistent alternation of masculine and feminine rhymes. ${ }^{26}$ Despite these differences, the poems are both examples of the Anacreontic ode, a flexible form based on relatively short lines, and generally associated with light subject-matter (Levarie 1973). Any element of levity is, however, counterbalanced not only by the poems' content - Van der Noot, who is never reluctant to sing his own praises, vigorously proclaims his poetic genius, spiritual superiority, and claims to immortality (Waterschoot ed. 1975: 3, 24I) - but by a monumentalizing tendency that runs throughout the second edition of the Poeticsche Werken. Visually, this is manifested in the use of architectural frames on each page: these are usually basic in form, but lend an inscriptional quality to the poems that they surround. Monumentalization of another kind is provided by prose commentaries, in at least one vernacular language, that follow many of the poems. The commentaries on the poems to Wonsel and David are in Italian and Castilian (Waterschoot ed. 1975: 2, 370); for most poems, a French version is also supplied. Each commentary takes the form of a dialogue, in which Dr Agricola - in other words Van der Noot's admirer Hendrik Ackermans - answers questions from a female interlocutor associated with a poet who worked in that language. The Italian questioner is Laura, commemorated by Petrarch; her French and Castilian counterparts are Cassandre, made famous by Ronsard, and Marfira, who is erroneously linked with the Catalan Petrarchist poet Joan Boscà. ${ }^{27}$ Although Ackermans is an authoritative character in the dialogues, all versions of the commentaries seem to have been composed by Van der Noot himself (Waterschoot ed. 1975:2, 46-55). As far as the odes to Wonsel and David are concerned, the commentaries add little that audiences able to read French or Dutch would not have gleaned from the poems themselves. Agricola simply explains to Laura and Marfira that Van der Noot aligns himself with timeless virtues rather than the barbarism of contemporary culture, and compares these claims to Horace's affirmation of poetic immortality, citing lines from the Odes (II. 2O. I-4). But the real significance of these and other commentaries lies not in what they say, but in their very presence alongside Van der Noot's poems, which they present as artistic objects worthy of scholarly reflection. The commentaries also underpin a further important feature of Van der Noots's selftranslations, a feature that is particularly apparent when two versions physically coexist in the same book: this is his performance of cosmopolitanism, of the ability to cross linguistic and cultural boundaries without apparent difficulty, not only in the composition of his poems but also in their reception. The preliminary bifolia for the second Poeticsche Werken edition produce a similar effect, as their various states all include material in very diverse languages (Waterschoot ed. 1975: 2, 26082). The first edition's paratext engages in a similar performance, in that the linguistic diversity of

25. On Boethius' influential reshaping of Aristotle's notion of contingency, see Heller-Roazen 2003: I-29. 26. The introductory stanza in each piece (Waterschoot ed. $1975: 2,367$ ) is in alexandrines, rhyming abbaccb (Wonsel) or abbacca (David). Rhymes are exclusively feminine in both stanzas.

27. These figures and others are introduced in the $1589-90$ version of the preliminary bifolium: Waterschoot ed. I975: 2, 266-68; 3, I36-37. Marfira does not appear in Boscà’s work, but rather in a poem by Diego (Hurtado) de Mendoza, which Boscà's widow included in a posthumous collection of work by her husband: Las obras de Boscán y algunas de Garcilasso de la Vega (Barcelona: Carles Amorós, I543; USTC 335095). See Vosters I985: 208-o9. 
the preliminary material reflects that of Van der Noot's verse (Waterschoot ed. I975: 2, I5O-59). By contrast, monumentalization is less fully developed in the earlier edition: pages are not framed, and no commentaries are supplied.

\section{Conclusion}

If the implied author of Van der Noot's verse is posited as translating from Dutch into French, a number of translational strategies can be identified. Perhaps most obviously, form and versification are key priorities. Stanzaic form, rhyme scheme, and metre tend to be maintained in the French versions, and indeed refined if necessary, to bring the material closer to the notions of good versifying practice that were prevalent in French literary culture. At the level of rhythm, to judge by the two samples analysed, earlier compositions seem to produce effects in essentially similar ways in both languages, whereas later work admits of more variation - albeit often in the service of equivalent general effects. Examination of samples has also generated findings of a methodological kind. A model based on Pensom's principles proves to give a clear account of the rhythmic and accentual effects that Van der Noot produces - not only in his French verse, as we might expect of a keen student of Ronsard and others, but also in the Dutch verse that he composes on French-style isosyllabic lines. This perspective offers great potential for more extensive analysis of Van der Noot's Dutch compositions, and indeed of the relatively few isosyllabic poems produced in Dutch by his contemporaries such as D’Heere.

Throughout the poet's career, questions of paratext, layout, and illustration are inseparable from translational strategies. In Het Theatre and Le Theatre, interactions between poem, image, and commentary allow an approach to translating verse that prioritizes formal concerns, and a box-ticking approach to ekphrasis, over semantic equivalence and indeed coherence. Where two versions appear together in the same edition, the organization of pages, openings, and books together with the role of images and their captions - may construct different relationships between Dutch and French versions. In the Cort begryp/Abregéa precarious balance is maintained, perhaps appropriately for the publication with which Van der Noot sought to impress the widest possible literary public on his return to Antwerp. In the Lofsang/Hymne, Dutch is constructed as chronologically prior and, through its preponderance in the paratext, as mediating between the poems and their public. The discreet precedence of Dutch, indeed, reflects the subtly different ways in which the poems themselves characterize the multilingual competence of Brabant's inhabitants:

Eerlicke mannen, vroom, geleerdt, wys en bescheyden,

Die oock, den meesten deel, spreken talen verscheyden.

('Honourable, pious, learned, wise and modest men, who also speak different languages for the most part')

Personages d'honneur, discretz, doctes et sages,

Qui, par l'esprit divin, parlent plusieurs langages.

(Zaalberg ed. 1958: 4-5)

The contrast between the categorical claim in the Hymne and the more circumspect formulation in the Lofsang tacitly acknowledges the reality that more monolinguals in the region were likely to be Dutch- than French-speakers. An altogether more elitist notion of multilingualism pervades the Poeticsche Werken. The linguistic diversity of each bifolium is reinforced by visual diversity, as 
different typefaces are used for different languages (Armstrong, forthcoming); the second edition adds frames and commentaries. All these features work in concert with the sporadic self-translations to construct an implied author who is emphatically cosmopolitan and multi-skilled - and apparently immune from self-doubt, as witness the profusion of voices that praise him in prose and verse, some of which are his own inventions (Brachin I959: I7; Waterschoot 1974: 73-74). Indeed, Van der Noot's evident self-regard and concern with immortality suggest that, throughout his career, his selftranslations were not only a commercial strategy that expanded his potential readership; they were also a means of attaining durable renown beyond his immediate environment, of securing a place within a French literary tradition that he considered especially prestigious.

If self-translation is considered as a negotiation between distinct literary and cultural traditions, as Hokenson and Munson advocate (2007: 206-O7), then we are able to acknowledge an important feature of Van der Noot's self-translations that extends beyond the specific strategies identified above. His work in Dutch is, of course, much more unusual than his work in French to experienced readers of verse in the respective languages. In this sense, the implied author is in some respects inverting the process of cultural transfer that commentators normally ascribe to him. By importing sonnets, isosyllabic versification, and the like from the French into the Dutch poetic tradition - and by translating poems by Marot, Du Bellay, and Ronsard into Dutch -, he is introducing foreign elements into the target literary system of Dutch poetry. However, if we cast French poetry as the target literary system, then we must acknowledge that Van der Noot is re-importing various elements that are already common in that system, out of a Dutch system in which they are much more unusual. To apply the terminology of Lawrence Venuti: Van der Noot's work is a foreignizing enterprise when considered as a French-Dutch process, but a domesticating enterprise when considered as a Dutch-French process (Munday 2OI2: 2I8-2I; Venuti 2OI3: 2-3). Given the probable bilingual composition of much of the poet's audience, we must assume that most readers were likely to have some appreciation of both these processes, and of their respective implications. Indeed, when the self-translations appeared together in the same book, audiences doubtless read them with close reference to each other. ${ }^{28}$

Van der Noot's modest reputation in the eyes of his contemporaries, and his lack of impact on later generations of poets, have been widely noted (e.g. Waterschoot 1974: 74-78). Leonard Forster has suggested that the print publication of his works may give them a disproportionate importance in the eyes of modern literary historians, since other Dutch-speaking poets of the late sixteenth century preferred to circulate coterie poetry in manuscript (I967: 296-98). Modern scholars consistently denigrate his French verse (Brachin 1959: I; Waterschoot 1974: 85-86). Yet Van der Noot's French verse involves much more than the regurgitated Pléiade commonplaces, and wholesale borrowing from established poets, for which he has been so often criticized. His self-translations reveal his close attention to two much more fundamental concerns, which indeed permeate his verse more generally: the ways in which a printed poem is inflected by its co-texts and physical presentation; and, even more crucially, the rhythmic possibilities through which verse affords any poet 'the raw materials for creating meaning outside language' (Pensom 20I8: I).

28. Philip Ford has suggested (2OI3: I58) that multilingual audiences read Latin and vernacular versions together in this way. 


\section{Works Cited}

Armstrong, Adrian. 2000. Technique and Technology: Script, Print, and Poetics in France, 1470-1550 (Oxford: Clarendon Press)

Armstrong, Adrian. 2007. 'Reception and Interference: Reading Jean Molinet's Rebus-Poems', Word and Image, 23: 350-6I < https://doi.org/IO.IO80/02666286.2007.IO435790 $>$

Armstrong, Adrian. Forthcoming. 'Géométries et textures de l'édition franco-néerlandaise au xvi ${ }^{\mathrm{e}}$ siècle', Manuscript and Text Cultures

Blanco, Mercedes. 20I8. 'Le plurilinguisme dans les Joyeuses Entrées d'Anvers (I52O-I635)', in Villes à la croisée des langues (XVP-XVIT siecles): Anvers, Hambourg, Milan, Naples et Palerme. Städte im Schnittpunkt der Sprachen (16.-1\%. Jahrhundert): Antwerpen, Hamburg, Mailand, Neapel und Palermo, ed. by Roland Béhar, Mercedes Blanco and Jochen Hafner (Genève: Droz), p. $5^{\mathrm{I} 7}-45$

Bostoen, Karel. 1997. 'Van der Noot's Apocalyptic Visions: Do You “See” What You Read?', in Anglo-Dutch Relations in the Field of the Emblem, ed. by Bart Westerweel (Leiden: Brill), p. 49$6 \mathrm{I}$

Bostoen, Karel. 20I6. Dichterschap en koopmanschap in de zestiende eeuw: Omtrent de dichters Guillaume de Poetou en Jan vander Noot, $2^{\text {nd }}$ ed. (e-book) < https://tinyurl.com/ybn74bfm $>$

Brachin, Pierre. 1959. Un disciple de Ronsard: Jan van der Noot 'patrice d'Anvers'(Paris: Minard)

Dorsten, Jan van. 1970. The Radical Arts: First Decade of an Elizabethan Renaissance (Leiden: University of Leiden Press; London: Oxford University Press)

Elst, Johannes van der. 1922. L'Alternance binaire dans le vers néerlandais du seizième siècle (Groningen: Haan)

Ford, Philip. 20I3. The Judgment of Palcemon: The Contest Between Neo-Latin and Vernacular Poetry in Renaissance France (Leiden: Brill)

Forster, Leonard. 1967. 'Iets over Nederlandse renaissancelyriek vóór Heinsius en Hooft', Tïdschrift voor Nederlandse Taal- en Letterkunde, 83: 274-302 < $\underline{\text { https://tinyurl.com/yzvosfpr }>}$

Friedland, Louis. 1956. 'The Illustrations in The Theatre for Worldlings', Huntington Library Quarterly, 19: I07-20

Haar, Alisa van de. 20I9. The Golden Mean of Languages: Forging Dutch and French in the Early Modern Low Countries (1540-1620) (Leiden: Brill)

Hadfield, Andrew. 20II. 'Edmund Spenser's Translations of Du Bellay in Jan van der Noot's $A$ Theatre for Voluptuous Worldlings', in Tudor Translation, ed. by Fred Schurink (London: Palgrave Macmillan), p. I43-60

Hokenson, Jan Walsh; Munson, Marcella. 2007. The Bilingual Text: History and Theory of Literary Self-Translation (Manchester: St Jerome)

Kazartsev, Evgeny. 20Io. 'Nederlands en Duits versritme in de vroegmoderne tijd', Neerlandistiek. $n l<\underline{\text { https://tinyurl.com/yagw5 } \lg \mathbf{x}}>$

Keizer, Joost; Richardson, Todd M. 2OI2. 'Introduction: The Transformation of Vernacular Expression in Early Modern Arts', in The Transformation of Vernacular Expression in Early 
Modern Arts, ed. by Joost Keizer and Todd M. Richardson (Leiden: Brill), p. I-23

Kossmann, Friedrich. 1922. Nederlandsch versrythme: De versbouwtheorieën in Nederland en de rythmischegrondslag van het Nederlandsche vers ('s-Gravenhage: Martinus Nijhoff)

Laumonier, Paul (ed.). 1925. Pierre de Ronsard Euvres complètes Iv: Les Amours (1552) (Paris: Hachette)

Laumonier, Paul (ed.). 1949. Pierre de Ronsard Euvres complètes XIV: Art poëtique françois (1565); Les Cuvres (1567) (Paris: Didier)

Levarie, Janet. I973. 'Renaissance Anacreontics', Comparative Literature, 25: 22I-39

Meeus, Hubert. 20I8. 'Jan van der Noot et les recueils plurilingues de poésie a Anvers', in Villes à la croisée des langues (XVT-XVIT siecles): Anvers, Hambourg, Milan, Naples et Palerme. Städte im Schnittpunkt der Sprachen (16.-1\%. Jahrhundert): Antwerpen, Hamburg, Mailand, Neapel und Palermo, ed. by Roland Béhar, Mercedes Blanco and Jochen Hafner (Genève: Droz), p. 67I-78

Melehy, Hassan. 20IO. The Poetics of Literary Transfer in Early Modern France and England (Farnham: Ashgate)

Munday, Jeremy. 20I2. Introducing Translation Studies: Theories and Applications, $3^{\text {rd }}$ ed. (London: Routledge)

Noot, Jan van der. 5 688. Le Theatre (London: John Day)

Pensom, Roger. 1993. 'Accent and Metre in French', French Language Studies, 3: 19-37

Pensom, Roger. 2018. Accent, Rhythm and Meaning in French Verse (Cambridge: Legenda)

Phillips, Arthur A. 1950. 'The Cultural Cringe', Meanjïn, 9: 299-302

Porteman, Karel; Waterschoot, Werner (ed.). I99o. Jan van der Noot Verscheiden poetixe wercken (Keulen, 1572): Het voorwerk (Leuven: Acco)

Richardson, Brian. 2OII. 'Introduction. The Implied Author: Back from the Grave or Simply Dead Again?' Style, 45: I-IO

Schlusemann, Rita. 20II. Niederländische Literatur bis 1550 (Berlin: De Gruyter)

Schutter, Frans De. 1967. Het vers van Jonker Jan van der Noot: Een ritmologische studie (Gent: Secretariaat van de Koninklijke Vlaamse Academie voor Taal- en Letterkunde)

Smit, Wisse A. P.; Vermeer, Wim (ed.). I953. Jan van der Noot 'Het Bosken'en 'Het Theatre' (Amsterdam: Wereldbibliotheek) $\langle$ https://tinyurl.com/ybq7Xw2f $>$

Sutch, Susie S. 20I7. 'Cross-Cultural Intersections in the Middle Dutch Translations of Le Chevalier délibéré by Olivier de La Marche', in The Multilingual Muse: Transcultural Poetics in the Burgundian Netherlands, ed. by Adrian Armstrong and Elsa Strietman (Cambridge: Legenda), p. I $33-48$

Swiggers, Pierre; Szoc, Sara; Van Hal, Toon. 20I8. 'Multilinguisme vertical et multilinguisme horizontal: la complexité des rapports de langues en Flandre au XVI siècle', in Villes à la croisée des langues (XVP-XVIT siecles): Anvers, Hambourg, Milan, Naples et Palerme. Städte im Schnittpunkt der Sprachen (16.-1\%. Jahrhundert): Antwerpen, Hamburg, Mailand, Neapel und Palermo, ed. by Roland Béhar, Mercedes Blanco and Jochen Hafner (Genève: Droz), p. I79-203

Tervarent, Guy de. 1997. Attributs et symboles dans l'art profane: Dictionnaire d'un langage perdu (1450-160o), $2^{\text {nd }}$ ed. (Genève: Droz) 
Venuti, Lawrence. 2013. Translation Changes Everything: Theory and Practice (London: Routledge)

Vosters, Simon Anselmus. 1985. 'Spaanse en Nederlandse literatuur: de wederzijdse invloeden', in Luister van Spanje en de Belgische steden 1500-1700, Brussel 1985, ed. by Jean-Marie Duvosquel and Ignace Vandevivere, 2 vols (Brussel: Gemeentekrediet), I: 205-24

Waterschoot, Werner (ed.). I969. Lucas d'Heere, Den Hof en Boomgaerd der Poësien (Zwolle: W. E. J. Tjeenk Willink) $<\underline{\text { https://tinyurl.com/ydzczwzt }>}$

Waterschoot, Werner. I97I. 'On Ordering the Poeticsche Werken of Jan van der Noot: An Analysis of the Sheets Printed by Arnout s'Conincx in I589-I590', Quarendo, I: 242-63

Waterschoot, Werner. I974. 'Jonker Jan van der Noot: Van Rederijkerij naar Renaissance', Jaarboek De Fonteine 1971-1972: 47-89 <https://tinyurl.com/ycqknbcl $>$

Waterschoot, Werner (ed.). I975. Jan van der Noot De 'Poeticsche werken', 3 vols (Gent: Koninklijke Academie voor Nederlandse Taal- en Letterkunde) $<$ https://tinyurl.com/ydyay8l $7>$

Waterschoot, Werner. 1988. 'Aksanten in Het Bosken', Tijdschrift voor Nederlandse Taal- en Letterkunde, IO4: II5-27 $\langle\underline{\text { https://tinyurl.com/y95 xheks }}>$

Waterschoot, Werner. 1992. 'Jan van der Noot's Het Bosken Re-Examined', Quarendo, 22: 28-45

Waterschoot, Werner. 1995. 'Marot or Ronsard? New French Poetics among Dutch Rhetoricians in the Second Half of the $16^{\text {th }}$ Century', in Rhetoric-Rhétoriqueurs-Rederijkers, ed. by Jelle Koopmans, Mark A. Meadow, Kees Meerhoff, and Marijke Spies (Amsterdam: North-Holland), p. I $4 \mathrm{I}-56$

Waterschoot, Werner. 1997. 'An Author's Strategy: Jan van der Noot's Het Theatre’, in Anglo-Dutch Relations in the Field of the Emblem, ed. by Bart Westerweel (Leiden: Brill), p. 35-47

Wille, Jacobus. 1952. 'De godsdienstige denkbeelden van Jan van der Noot in zijn Keulsche Periode', in Studies aangeboden aan Prof. Dr. Gerard Brom (Utrecht: Dekker en Van De Vegt), p. $223-44$

Witstein, Sonja F. 1965. Deverzencommentaar in 'Het Theatre'van Jan van der Noot (Utrecht: Instituut voor Algemene Literatuurwetenschap aan de Rijksuniversiteit te Utrecht)

Zaalberg, Carlo A. 1954. 'Das Buch Extasis'van Jan van der Noot (Assen: Van Gorcum)

Zaalberg, Carlo A. (ed.). 1956. The Olympia Epics of Jan van der Noot: A Facsimile Edition of 'Das Buch Extasis', 'Een Cort Begryp der XII. Boeken Olympiados' and 'Abregé des douze livres Olympiades'(Assen: Van Gorcum)

Zaalberg, Carlo A. (ed.). 1958. Jan van der Noot Lofsang van Braband/Hymne de Braband (Zwolle: W. E. J. Tjeenk Willink) < https://tinyurl.com/y6uvf5kz $>$

Zaalberg, Carlo A. 1965. 'Het Cort Begryp van Jan van der Noot als episch werk', De Nieuwe Taalgids, 58: 252-59 <https://tinyurl.com/yzyozvxn> 